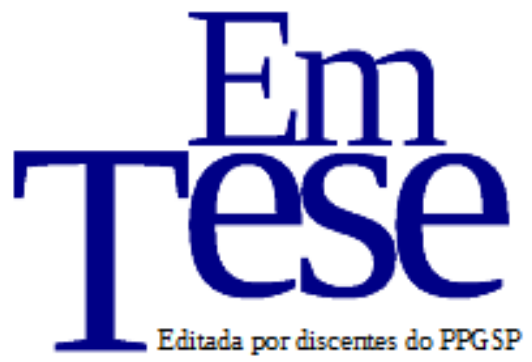

UFSC

PPG SP PROG RAMA DE

PÓS-GRADUAÇÃO EM

Sociologia

Política

v. 15, n. 1 (parte II), p.75-102, mar./abr., 2018.

http://dx.doi.org/10.5007/1806-5023.2018v15n1p75

\title{
Roberto Schwarz e a crítica negativa: notas sobre crítica e dialética na periferia do capitalismo ${ }^{1}$
}

Rafael Marino ${ }^{2}$

\begin{abstract}
Resumo: Com este texto, pretende-se esquadrinhar e deslindar alguns pontos daquilo que Schwarz entende como crítica negativa, procurando, ao mesmo tempo, identificar no autor e em algumas de suas obras as grandes linhas de um programa crítico com esse sentido. Para tal, lançaremos mão, principalmente, de algumas obras, entrevistas e comunicações feitas pelo autor acima citado e de alguns comentários de Paulo Arantes, sobre o Pensamento Político e Social brasileiro em geral e sobre o pensamento de Schwarz em particular. Além de uma digressão teórica sobre influências da teoria crítica europeia sobre o pensamento do crítico literário. De posse de tudo isso, acreditamos identificar no autor a estruturação de uma crítica ou dialética negativa, da qual podemos depreender a busca por uma crítica radical à ordem capitalista mundial e ao reino da mercadoria, juntamente com suas iniquidades.
\end{abstract}

Palavras-chave: Roberto Schwarz; Pensamento Político e Social Brasileiro; Tradição crítica brasileira; Dialética negativa; teoria crítica brasileira.

\section{Roberto Schwarz and the negative critique: notes about critique and dialectis on the periphery of capitalism}

\begin{abstract}
This text aims to attentively examine some aspects of what Schwarz understood as negative critique as well as to identify in his writings the foundations of a critical program in this direction. In order to do so, we will be taking a look at some works, interviews and presentations by the above mentioned author and a few comments made by Paulo Arantes on Brazilian social and political thought in general and on Schwarz's ideas in particular. In addition to a theoretical digression on the influences of european critical theory on the thinking of the literary critic. Based on all this we are confident about demonstrating that Schwarz structures a certain negative critique or dialectics, from which we can infer a search for a radical critique of the world capitalist order and of the commodity realm, along with its inequalities.
\end{abstract}

Keywords: Roberto Schwarz; Brazilian political and social thought; Brazilian critical tradition, Negative dialectics; Brazilian critical theory.

\footnotetext{
1 (cc) EY Esta obra está licenciada com uma Licença Creative Commons Atribuição 4.0 Internacional. ${ }^{2}$ Graduado em Ciências Sociais pela Universidade São Paulo (USP) e Mestrando em Ciência Política pela mesma universidade (PPGCP); membro dos grupos Pensamento e Política no Brasil e Sequências Brasileiras, ambos vinculados ao CENEDIC - USP. Bolsista da Coordenação de Aperfeiçoamento de Pessoal de Nível Superior (CAPES). E-mail: rafael.marino50@gmail.com.
} 


\section{Introdução}

Seguindo algumas lições advindas do ensaio de Roberto Schwarz sobre o seminário de $O$ Capital $^{3}$, além de pontuar e identificar a constituição de um nova e preciosa intuição sobre o Brasil, em que se juntava e se articulava a peculiaridade política e sociológica do país à ordem e história contemporânea do capital (SCHWARZ, 2014, p. 113; 2017, p. 25) - algo fundamental a sua obra posterior -, é possível identificar em seu final algumas críticas ao mesmo seminário 4 . Críticas as quais poderiam ser divididas em três grupos distintos. Em primeiro lugar, não teria havido por parte do grupo um interesse mais profundo pela crítica de Marx ao fetichismo da mercadoria. Em segundo, faltou uma compreensão da importância dos frankfurtianos, em dois flancos: i) - tanto em sua apreensão realista, crítica e articulada de experiências, cada uma a seu modo, produtoras de barbárie, como a do Nazismo, Socialismo Soviético e o American way of life dos E.U.A; ii) - quanto de sua visão crítica ao lado degradante da mercantilização e da industrialização da cultura, não prestando atenção ao caráter problematizador e radical da arte moderna - inclusive a brasileira - frente ao curso do mundo. Como terceiro elemento, poderíamos indicar o fato de não terem conseguido forjar um instrumento literário à altura de suas descobertas e achados, confinando-os ao código acadêmico e a uma circulação restrita - bem ao contrário de ensaístas como Freyre ou Buarque de Holanda e sua vinculação às letras modernistas (SCHWARZ, 2014, p. 127).

Em resumo, ao ficarem presos à estreiteza da problemática nacional, desejando a superação de nosso atraso relativo, bem como a nossa brutal inorganicidade social e engajando-se sistematicamente em achar uma saída positiva e programática para o Brasil, acabavam por deixar de lado o enfrentamento crítico das indecorosas e nada provincianas imbricações entre atraso, progresso e a lógica de produção mercantil. Ou, em outras palavras, a crítica dialética negativa era deixada de lado em prol de um compromisso progressista e positivo, para todos os efeitos, cujo alvo era um Brasil coeso e participante do progresso do capitalismo em meio ao concerto das nações (ARANTES, 1998). Uma postura bastante distinta da encontrada em Marx, cuja produção madura não se voltava para a salvação alemã, postura também encontrada, guardada as devidas proporções e sem forçar a nota, no próprio Roberto Schwarz e em seus escritos.

Com estas aproximações, tanto em relação a Marx, quanto em relações aos teóricos da primeira geração da chamada Escola de Frankfurt, não se pretende uma postura bovarista, baseada

\footnotetext{
${ }^{3}$ Para mais sobre a dinâmica e composição do grupo em questão ver: (SCHWARZ, 2014, p. 105 - 106). Para mais sobre o grupo em geral ver: (LAHUERTA, 2008, p. 311 - 357); (RODRIGUES, 2011); (SADER, 2005, p. 150 177).

${ }^{4}$ Quanto ao referido seminário Marx, seguindo argumentação de Golçalves \& Brito (2017) - baseados na ideia de Ricupero (2000) e Tapia (2002) sobre a noção de nacionalização do marxismo -, é licito afirmar que seria um capítulo essencial da nacionalização do marxismo no Brasil.
} 
no enaltecimento provinciano de uma figura da crítica nacional e sim esquadrinhar e deslindar os pontos daquilo que o nosso crítico austro-brasileiro entendia como a crítica negativa, procurando, ao mesmo tempo, identificar no autor e em sua obra as grandes linhas deste programa crítico ${ }^{5}$. Para tal, lançaremos mão tanto de algumas digressões teóricas e formativas sobre a tradição contraditória $^{6}$ - ou, ao menos parte dela -, quanto do comentário de alguns textos nos quais seria possível explicitar as linhas acima pretendidas.

\section{Pequena digressão frankfurtiana, ou intemezzo teórico e formativo}

Antes de dar início a esta seção, é forçoso ter em mente o fato de o nosso crítico de modo algum pretender aplicar as teses e escritos dialéticos anteriormente citados, até porque, metodologicamente falando, o "reconhecimento do primado do objeto impõe a diferença específica da obra de Schwarz", obrigado a reconhecer "aquilo que nos objetos contradiz e nega, de modo produtivo, as categorias dispostas previamente para a análise" (ALMEIDA, 2007, p. 49). Esta feita obriga a uma aproximação criativa, diferencial e desconfiada quanto aos mestres europeus, como tentaremos expor posteriormente ${ }^{7}$.

De todo modo, entroncando no assunto proposto, é preciso notar uma influência, mesmo que diferencial, do filósofo marxista húngaro György Lukács no crítico austro-brasileiro, a qual dá notícias nos estudos do Capital, principalmente a sua influência quanto a necessidade de se manter uma ortodoxia quanto ao método e não quanto as teses ou resultados anteriormente elaborados $^{8}$. Todavia, há uma especificidade da apropriação feita por Schwarz em relação ao húngaro, aproveitando-se também de obras como: A alma e as formas, A teoria do romance e $O$ romance histórico 9 . Segundo Paulo Arantes (1992), a primeira coletânea de ensaios de nosso crítico, intitulada A Sereia e o Desconfiado (SCHWARZ, 1965), teria como linha geral a seguinte:

\footnotetext{
${ }^{5}$ Com isso não se quer apontar um desenvolvimento intelectual linear e sem tensões no pensamento de Schwarz tensões e mudanças que se devidamente exploradas nos levaria à escrita de outro artigo, logo escapando do escopo aqui proposto - mas sim indicar que em meio a sua obra poder-se-ia identificar a constituição de uma crítica negativa distinta de seus pares intelectuais.

${ }^{6}$ Schwarz chama assim a tradição dialética composta por Lukács, Brecht, Benjamin e Adorno, com o fito de marcar a diferença existente entre eles - mesmo que enfatize certa complementariedade - e a centralidade da contradição no método dialético (SCHWARZ, 2012, p. 13, d).

${ }^{7}$ Em entrevista à Corredor (2001-2002, p.34), Schwarz afirmou ter buscado certa complementariedade entre os autores desta tradição contraditória. Sem negar isto, é lícito vislumbrar que em meio a essa síntese Adorno e sua crítica negativa terem sido termos mais relevantes, algo que pode ser vislumbrado, por exemplo, em outra entrevista de Schwarz sobre o crítico frankfurtiano (2012b, p. 44-52).

${ }^{8}$ De acordo com o próprio filósofo húngaro: "Em matéria de marxismo, a ortodoxia se refere antes e exclusivamente ao método. Ela implica a convicção científica de que, com o marxismo dialético, foi encontrado o método de investigação correto, que esse método só pode ser desenvolvido, aperfeiçoado e aprofundado no sentido dos seus fundadores" (LUKÁCS, 2012, p. 64).

${ }^{9}$ Um trabalho mais sistemático e completo que elabora de modo mais substantivo a relação de Lukács e Schwarz quanto a crítica literária pode ser encontrado em: (WAIZBORT,2007, p. 37 - 87). Advertimos o fato de que não seguimos de todo a interpretação do sociólogo, até porque a presença de Adorno, como indicado adiante, também fora essencial nos escritos de nosso crítico sobre Machado de Assis.
} 
“os problemas do Realismo e suas alternativas contemporâneas, examinados em função da coerência construtiva das obras, e o conjunto, à luz das grandes categorias explicativas da alienação moderna e seus antídotos" (ARANTES, 1992, p. 53). Não à toa Leandro Konder escreve na "orelha" do livro, ser um dos méritos de Schwarz ter dado um passo decisivo em direção a uma crítica humanista e lukácsiana (KONDER, 1965, orelha de livro). Colocação que levanta alguns problemas, já que como Arantes mesmo aponta, para um programa de crítica literária o qual tem em vista um sistema de mediações historicamente específicas, era um primeiro passo de suma importância, mas "uma coisa é pô-la em prática no estudo de autores europeus, outros quinhentos quando os autores são brasileiros" (ARANTES, 1992, p. 53). Fica perceptível na leitura do livro de estreia que os autores europeus tinham maior relevo e destaque que os nacionais, mas por que isso ocorreria? Arantes responde:

(...) no que respeitava à grande literatura europeia ali estudada, pode-se dizer que a vida do crítico se encontrava em boa parte facilitada pela sólida tradição social e intelectual de conhecimentos acumulados que balizavam o terreno histórico sobre o qual se erguia a experiência literária a ser decifrada. Um romance de Balzac, embora integralmente construído e carecendo de um esforço analítico equivalente, já se apresentava por assim dizer com a matéria social que lhe estrutura os conflitos previamente ordenada. Não era este o caso dos escritores brasileiros, onde quase tudo estava por fazer, a começar pelo básico: o reconhecimento do ritmo histórico singular de uma formação social em função da qual se organizava o sistema das obras (Ibid., p. 54, grifos meus) ${ }^{10}$.

De posse deste argumento é sugestivo pensar que o comentário de Konder passa a ter em si uma tensão essencial, a qual, sob a batuta do próprio Schwarz, pode ser assim apresentada: "Lukács construiu um modelo para a história europeia das ideias e do romance que depende da evolução histórica geral do feudalismo para o capitalismo e para o socialismo" (SCHWARZ, 2001 - 2002, p. 21), mostrando como essa construção é poderosa e funciona ativamente na obra de romancistas e filósofos ${ }^{11}$. Contudo, quando se olha para a América Latina, em geral, e para o Brasil, em particular, percebe-se que essa sequência gira em falso, porque, aqui, a sequência vai do colonialismo para a tentativa de construção de um Estado Nacional, ou seja, não é uma sequência universal. Consequentemente, haveria pela frente o desafio de apreender a dinâmica de uma formação específica diversa, mas não alheia ao capitalismo mundial, apreensão que teria o seu momento principal nos estudos de $O$ capital e suas consequências, anteriormente apresentado e posteriormente melhor burilado de acordo com a necessidade dos argumentos aqui expostos.

É notável que apesar da especificidade das obras citadas anteriormente, o que salta aos olhos é a apropriação feita pelo crítico da relação propriamente dialética entre forma literária e

\footnotetext{
${ }^{10}$ Para mais sobre as continuidades e inflexões entre a obra do jovem e a do já maduro Roberto Schwarz, ver: (FISCHER, 2007, p. 78-95).

${ }^{11}$ Comparando-se os livros A sereia e o desconfiado (1965) e O pai de família e outros estudos (1978) vê-se uma inflexão na obra de Schwarz, exemplificado nos ensaios sobre Kafka: naquele um juízo crítico negativo frente aos escritos do alemão e neste uma visão mais aberta quanto aos procedimentos anti-realistas e seus resultados críticos e figurativos (ARANTES, 1994, p. 228).
} 
processo social, mais especificamente, as relações entre luta de classes e composição literária, ao menos em sua formulação europeia:

(...) devo muito a Lukács: devo a ele meu esquema do romance europeu. Como ficou dito, sua construção não corresponde às realidades brasileiras. Porém, como é uma notável formulação das grandes linhas da história social e literatura europeia, ela faz ver os pontos em que a sociedade e a cultura brasileira se desvia de seus muitos estimados modelos europeus. Esses desvios eram dolorosamente percebidos pelos contemporâneos, que os viam como falhas nacionais e, nos melhores casos, as transformavam em elementos de crítica social e produção artística. Como meu interesse era examinar essas questões, os estudos de Lukács sobre o romance entraram de modo substancial, ainda que negativo, em meu trabalho (SCHWARZ, 2001 - 2002, p. 34).

Tal apropriação é detalhadamente explorada por Waizbort em seu livro A passagem do três ao um, da qual ressaltaremos algumas colocações. De saída, em seu livro sobre o romance histórico, Lukács deixa a relação entre literatura e sociedade às claras: o "ponto metodológico decisivo é a investigação da interação do desenvolvimento econômico e social com a visão de mundo e a forma artística que se engendram a partir desses desenvolvimentos" (LUKÁCS, 2011, p.29) ${ }^{12}$. Um aspecto metodológico coloca uma diferenciação de extrema importância: a) uma situação histórica de ex-colônia "engendra uma forma, a partir da qual o romancista trabalha, isto é, cria sua forma literária” (WAIZBORT, 2007, p. 42) de modo algum igual à europeia; b) o desenvolvimento histórico na Europa engendra uma forma peculiar para o romance realista. Em outras palavras, se a compreensão da forma exige a compreensão do processo social e este é o próprio desenvolvimento desigual e combinado do capitalismo, é necessário que compreendamos a especificidade do desenvolvimento capitalista no Brasil - diverso, mas não alheio ao resto do mundo - para compreender a forma romance nestas bandas ${ }^{13}$.

Adiantando o passo, o qual daremos definitivamente na próxima seção, em Machado de Assis, pelas mãos de Schwarz, enxergaríamos um certo realismo específico ${ }^{14}$. Assim sendo, o crítico austro-brasileiro quer argumentar que, à maneira de Balzac, Machado de Assis, conseguiu transfigurar a fantasia romanesca em forma (SCHWARZ, 2012a, p.190), de forma que o escritor mesmo que figurando com liberdade a chamada vida popular, consegue "exprimir um nexo histórico decisivo e, assim, retratar um movimento fundamental da sociedade" (WAIZBORT,

\footnotetext{
${ }^{12}$ Não que antes, em sua fase mais jovem e "hegeliana" a forma não fosse objeto de seus ensaios, pelo contrário, como pode ser visto aqui: "O destino do crítico é traçado no momento crucial em que as coisas se tornam forma, em que todo sentimento e toda vivência até então aquém e além das formas recebem uma forma, fundem-se e condensam-se em forma" (LUKÁCS , 2015, p. 40).

${ }^{13}$ É preciso lembrar também que Schwarz (2001 - 2002, p. 32-34; 2012b, p. 48) enfatiza certo afastamento de Lukács, pois este teria, segundo o nosso crítico, desenvolvido em algumas de suas obras de maturidade sobre a literatura uma visão por vezes doutrinaria e normativa, cujo ponto de fuga seria o comunismo soviético, impedindo-o de apreender o caráter crítico da arte de vanguarda.

${ }^{14}$ É importante frisar que o conceito de realismo em Lukács (2009) é um tanto amplo, por abarcar autores deveras distintos ao modo de Cervantes, Shakespeare e Tolstói, até porque o fundamental do romance realista seria conseguir figurar os elementos ou determinações essências da história (Ibid., p. 201-202), o que cada um ao seu modo logrou fazer.
} 
2007, p. 61 $)^{15}$. Se no francês o nexo seria o dinheiro, no brasileiro seria o paternalismo, ou, mais especificamente, o favor - algo melhor tratado posteriormente ${ }^{16}$.

Também a relação de Schwarz com o filósofo e pensador alemão Walter Benjamin será diferencial. Por exemplo, para o alemão, em seu ensaio "O narrador. Considerações sobre a obra de Nikolai Leskov" (BENJAMIN, 2011, p. 197 - 222), a construção do contraste entre narrativa pré-capitalista e romance se deu sob o fundo de transição do artesanato para a produção industrial; no Brasil o mesmo seria impossível (SCHWARZ, 2012a, p. 59, rodapé no 20). Nesse bojo, o causo seria uma forma de contribuir para a casuística das situações humanas e das tradições regionais, servindo para divertir e fortificar, já o Romance serviria para desvelar, tendo "compromisso com a verdade sobre .a vida numa formação social determinada", fazendo parte de um movimento de crítica, mesmo que não o queira. Romance, como uma forma histórica dentre outras, o qual pode mesmo barrar, até certo limite, a figuração literária nacional; o mesmo não ocorre com o causo, pois juntando os enleios da vida - concepção a-histórica -, e "o apreço desimpedido pela reprodução da circunstância, que lhe permite um realismo que entre nós o Realismo de tradição literária não só não alcançava, como dificultava” (Ibid., p. 60). Um paradoxo que Schwarz (2012a, p. 64) sugere ser melhor ajustado em José de Alencar.

A exposição acima serve para indicar a importância de Benjamin no pensamento do crítico $^{17}$. No entanto, sua influência não se limita aí, aparecendo também no ensaio: "A obra de arte na era de sua reprodutibilidade técnica" (BENJAMIN, 2011, p. 165 - 197). Cujo intuito, grosso modo, é mostrar como o valor-de-culto fora sendo substituído pelo valor-de-exposição e a aura da produção artística foi esvaindo, e os fatores sociais de seu declínio derivam de duas circunstâncias ligadas à crescente difusão e intensidade dos movimentos de massa: 1) uma preocupação apaixonada em fazer as coisas "ficarem mais próximas" e 2) a superação do caráter único de todos os fatos via reprodutibilidade técnica. Um processo que teria sua melhor "prova" no contraste entre a fotografia e o filme, com as artes "tradicionais", à maneira das artes plásticas. Argumentação que perpassa grande parte da obra de Schwarz, mas que pode ser encontrada de modo mais contundente em ensaios como: "Notas sobre vanguarda e conformismo", "A Santa Joana dos Matadouros", "O progresso antigamente" e seus textos sobre cinema ("8 1/2 de Fellini,

\footnotetext{
${ }^{15}$ Waizbort (2007) enfatizará em meio a obra de Schwarz a presença do pensamento de Eric Auerbach, endereçando a este a ideia da existência de formas distintas de realismo (p. 62), todavia é preciso enfatizar que isso também aparece fortemente em Lukács, como ressaltado em rodapé anterior.

16 É preciso dizer que nos distanciamos aqui da interpretação de Rodrigues (2011), para quem Schwarz teria "desprezado" o Machado de Assis "romântico" devido à sua vinculação à ideia lukáciana de que o grande romance é o realista (p. 2011). A noção de realismo deste é ampla, como colocado anteriormente e a crítica imanente daquele não abarca tal juízo.

${ }^{17}$ Para um estudo pormenorizado e sugestivo sobre a recepção do pensamento de Walter Benjamin na Intelligentsia brasileira, em geral, e Roberto Schwarz, em particular, ver: (PRESSLER, 2006).
} 
“O cinema e Os fuzis" e "O fio da meada") ${ }^{18}$ (SCHWARZ, 2008c, p. 47 - 55; 2012, p. 87 - 107; p. $107-115)$.

Antes de entrar no próximo tópico, é preciso passar, mesmo que sumariamente, pela influência decisiva de Theodor W. Adorno ${ }^{19}$ e sua crítica negativa sobre o pensamento do crítico literário - além da semelhança quanto a "atitude geral de crítico, inteiramente aberto, atentíssimo, e sobretudo movido pela ambição mais alta possível” (SCHWARZ, 2012b, p. 45) -, podendo ser destacada em 3 pontos: i) tradição e forma; ii) forma ensaística; iii) o avanço do fetichismo. Começo do primeiro, abaixo.

Seguindo o argumento do próprio crítico, os ensaios sobre literatura e nova música do autor alemão foram os que mais o marcaram, pois "neles a discussão sobre o funcionamento da forma, de sua substância sócio histórica, de sua revolução moderna, de seu caráter construído e exploratório, e sobretudo de sua lógica objetiva, está mais abstrata e clara” (Ibid., p. 48). Para ambos, a forma não seria algo por assim dizer a-histórico, mas sim, nas palavras do crítico austrobrasileiro, aquilo através do qual haveria a junção de arte e sociedade, agindo como

(...) um princípio mediador que organiza em profundidade os dados da ficção e do real, sendo parte dos dois planos. Sem descartar o aspecto inventivo, que existe, há aqui uma presença da realidade em sentido forte, muito mais estrita do que as teorias literárias costumam sugerir. Noutras palavras, antes de intuída e objetivada pelo romancista, a forma que o crítico estuda foi produzida pelo processo social, mesmo que ninguém saiba dela. Trata-se de uma teoria enfática do realismo literário e da realidade social enquanto formada. Nesta concepção, a forma dominante do romance comporta, entre outros elementos, a incorporação de uma forma da vida real, que será adicionada no campo da imaginação. Por outro lado, não se trata de um realismo espelhista, pois uma forma não é toda a realidade, além do que ela pode se combinar com elementos historicamente incaracterísticos (SCHWARZ, 2012c, p. 141) ${ }^{20}$.

Formulação que em muito se aproxima daquela do filósofo alemão, encontrada em sua Teoria Estética, na qual o frankfurtiano argumenta que a arte, ao mesmo tempo em que não apreende o que há de mais imediato no real, encerra nela mesma um ente empírico. Até porque mesmo que aquela se oponha ao imediato empírico por meio do momento da forma - lembrando que a mediação entre conteúdo e forma não deve ser pensada sem a sua devida distinção -, é importante ter-se em vista o fato de a forma estética ser conteúdo sócio-histórico sedimentado. Como exemplo, poder-se-ia lembrar que as formas aparentemente mais puras, à maneira das formas musicais, remontam em seus pormenores a algo ligado ao conteúdo, como a dança para o

\footnotetext{
${ }^{18}$ Para um comentário detalhado sobre eles ver: (XAVIER, 2007,p. 212 - 226).

${ }^{19}$ Para além do já citado e sugestivo ensaio de Almeida (2007, p. 44 - 54), há também um interessante artigo no qual Silvio Camargo estuda a influência da Escola de Frankfurt no Brasil, tratando da relação entre Adorno e Schwarz (CAMARGO, 2014, p. 105 - 133).

${ }^{20}$ Segundo Arantes (1994, p. 231-234), nessa concepção de forma acima exposta poder-se-ia notar também certa influência da leitura ontológica feita por José Arthur Giannotti de $O$ capital, tomando deste a ideia de que "a realidade social, por conhecer um processo de constituição categorial, já se apresenta, diante do escritor que a toma como referência global, enquanto formada" (Ibid., p. 288).
} 
domínio artístico citado (ADORNO, 1970, p.15). Para ambos, também, uma inovação artística e, consequentemente, formal só valeria a pena enquanto "conteúdo de verdade", caso estivesse assentado em um tradicionalismo severo ${ }^{21}$, pois as mudanças radicais só poderiam ocorrer caso aquele estivesse presente, ao modo, por exemplo, da relação crítica de Schöenberg e seu atonalismo livre, com o expressivismo de Richard Wagner e a tradição romântica na música alemã e austríaca (ADORNO, 2011, p. 39).

Passemos agora para a importância da forma nos escritos de Adorno e sua relação com a escrita do crítico austro-brasileiro. No crítico alemão, o predomínio da "forma ensaio em seus textos e em seu estilo deriva tanto de sua afinidade e militância na vanguarda modernista, como da premissa de que a exposição não é indiferente à teoria” (MUSSE, 2015). Identificada com uma concepção de verdade, com acentuado núcleo temporal e histórico, em que "o conteúdo histórico torna-se, em sua plenitude, um momento integral dessa verdade” (ADORNO, 2012, p. 26); marcada por uma relação sui generis com a experiência, tornando-se uma relação com a história mesma, pois a experiência "imediatamente"22 individual, a partir da qual a consciência como ponto de partida, "é ela mesma já mediada pela experiência mais abrangente da humanidade histórica" (Idem). Uma forma estilística que faz sistema nos ensaios de Schwarz, visto que, como bem nota Cevasco (2007), o estilo de nosso autor vai, a cada parágrafo, dando corpo e enchendo de novas determinações a questão a ser tratada; começando, muitas vezes, com a inadequação entre a nossa realidade e às categorias importadas - calcadas, via de regra, em pressupostos materiais e históricos outros -, um dos motores da dualidade essencial dos países na periferia do capitalismo. Posteriormente, apreende o que determina a dualidade, ao mesmo tempo que a transforma em uma unidade, caracterizada pela fórmula "diverso mas não alheio", lembrando que, se o primeiro termo aponta para as especificidades sócio-históricas das diversas realidades, já o segundo aponta para o elemento determinante desta disparidade, a saber: a dinâmica e a lógica do capital. Por último, nosso crítico daria mais um passo: "essa dualidade, instituída e desmanchada em unidade pelo sistema que a rege, acaba permitindo que a experiência intelectual e artística do Brasil possa ser reveladora dos mecanismos reais do funcionamento do processo" (CEVASCO, 2007 , p. 19). ${ }^{23}$

\footnotetext{
21 "Vocês que leram Adorno lembram a descrição exata que ele faz, no caso da música de Schöenberg, da complementariedade entre o tradicionalismo severo e a capacidade de revolucionar uma forma. É como se na ausência de tradição rigorosa as mudanças radicais se tornassem impensáveis" (SCHWARZ, 2014, p. 21).

${ }^{22}$ Entre aspas, pois como já dizia Hegel: “(...) não existe nada, nem no céu, nem na natureza ou no espírito ou seja lá onde for, que não contenha imediatamente a imediaticidade bem como a mediação, de modo que essas duas determinações se mostram como inseparadas e inseparáveis e aquela oposição como algo nulo" (HEGEL, 2011, p. $50)$.

${ }^{23}$ Ponto que se liga àquilo que Candido falava sobre o intelectual latino-americano, que precisa ser ao mesmo tempo "ele e mais um outro". Outro que "era a cota de cultura europeia da qual necessitava para se formar". Experiência muito diferente da do intelectual europeu, que poderia ser apenas ele e sua circunstância (CANDIDO, 2007, p. 15).
} 
Em suma, é na própria forma ensaio que a experiência intelectual e artística da periferia do capitalismo é formalizada e sedimentada, tornando-se um ganho não só estilístico, mas também de grande aproveitamento crítico. Esse esforço intelectual, nada provinciano, do crítico austrobrasileiro, liga-se ao terceiro termo de sua relação com Adorno: o avanço do fetichismo.

Lukács, em História e Consciência de classe, entenderá a reificação como um componente estrutural de toda a vida social, como se a história da expansão do capitalismo fosse a histórica da expansão do fenômeno da reificação para todas as esferas da vida, que tem sua base material na forma mercadoria. Forma esta que no capitalismo passa a ser universal, conformando a sociedade em todos os níveis, podendo-se "descobrir na estrutura da relação mercantil o protótipo de todas as formas de objetividade e de todas as suas formas correspondentes de subjetividade na sociedade burguesa" (LUKÁCS, 2012, p. 194). Um fenômeno que pode ser entendido, de maneira sumária, como um "processo através do qual os produtos da atividade, do trabalho humano (e o próprio trabalho humano) se tornam um universo de coisas e relações entre coisas, um sistema 'coisificado', independente e estranho aos homens, que os domina por suas próprias leis" (LÖWY, 2008, p. 72). E que produz reflexos na própria consciência dos homens.

Em O Capital, quando Marx descreve a forma mercadoria, também descreve, historicamente, a gênese do pensamento conceitual abstrato e a divisão entre os trabalhos intelectuais e manuais, mostrando que a troca de mercadorias envolve uma abstração dupla: i) abstração do caráter mutável da mercadoria durante o ato de troca; ii) abstração do caráter empírico, concreto e particularizado da mercadoria. Para trocar uma mercadoria X por uma mercadoria $\mathrm{Y}$, qualitativamente diferentes, necessariamente é preciso fazer uma abstração, que é eminentemente social e não, apenas, intelectual. Já que para trocar mercadorias é preciso compará-las, a partir do tempo de trabalho necessário à sua produção ${ }^{24}, \operatorname{logo}$, independente do seu caráter qualitativo, passando a ser "essencialmente dispêndio de cérebro, nervos e músculos, sentidos" (MARX, 1983, p. 70) num determinado espaço de tempo. Até por isso Marx fala em uma forma mercadoria ${ }^{25}$, que Lukács irá tomar como um o protótipo de todas as formas de objetividade e subjetividade na sociedade burguesa, em que a forma mercantil, historicamente, passa a ser dominante, em um processo que pretendo explicar a seguir.

Nesse bojo, a consequência objetiva da coisificação é o aparecimento de um mundo de coisas acabadas e de relações entre coisas, com leis que enxergamos como inexoráveis e inelutáveis, as Leis do Mercado. Já a consequência subjetiva é a transformação do trabalho em

\footnotetext{
24 "Tempo de trabalho socialmente necessário é aquele requerido para produzir um valor de uso qualquer, nas condições dadas de produção socialmente normais, e com o grau médio de habilidade e de intensidade do trabalho" (MARX, 1983, p.48).

${ }^{25}$ Schwarz bem lembra a importância da discussão sobre a forma em Lukács: "Suas análises de conteúdo sempre levam a consequências composicionais. Nesse sentido, ele procura as energias formais do conteúdo, verificando a consistência de sua realização literária" (SCHWARZ, 2001 - 2002, p. 35). Para mais ver: (MACEDO, 2009, p. 165 231).
} 
mercadoria, portanto, o operário mesmo é coisificado, já que se depara com o seu trabalho alienado de si, passando a ser uma mercadoria. Nesse sentido, podemos afirmar que no proletário a reificação atinge a sua face mais radical - algo que se constitui como um passo fundamental em Lukács, para quem essa mecanização racionalizada passa a penetrar até a alma do trabalhador, de sorte que até suas qualidades psicológicas são separadas da totalidade da personalidade deste e passam a ser "objetivadas em relação a esta última, para poderem ser integradas em sistemas especiais e racionais e reconduzidas ao conceito calculador" (LUKÁCS, 2012, p. 202).

Adorno, juntamente com Horkheimer, por sua vez, irá aceitar em parte o diagnóstico lukácsiano, até porque, grosso modo, indicará a reificação em relação aos indivíduos e não mais em relação às classes sociais, ligando-se, assim, à consciência e à inconsciência dos sujeitos. Além disso, em seu famoso livro A dialética do esclarecimento: fragmentos filosóficos, a reificação é entendida como um fenômeno que se dá para além do capitalismo, ou seja, as raízes de racionalidade instrumental são muito mais antigas do que o início do capitalismo. A tese é provocante e tem sua materialização com a exposição da astúcia de Ulisses na epopeia de Homero, em que este utiliza todos os meios possíveis para atingir o fim de regressar à ilha de Ítaca, onde era rei, senhor de terras e rebanhos. Com isso, os autores têm a intenção de explicar que junto a todo modelo de racionalidade o qual elege como "fim último não a felicidade, mas objetos que, na verdade, seriam apenas meios de autopreservação da vida humana, reside uma indelével sombra da mais crassa irracionalidade" (DUARTE, 2008, p. 13).

Dessa feita, pode-se entender o porquê de Adorno e Horkheimer rejeitarem a visão de que a racionalidade seria o contrário da mitologia e mais: propõe que os mitos nada mais seriam do que uma antecipação "da racionalidade que faz dos meios os fins últimos da existência humana, em suma, da racionalidade instrumental" (Idem). Esclarecedora, nesse sentido, é a cena XII da Odisseia (HOMERO, 2013, p. 205 - 220), na qual Ulisses ordena aos marujos para que tapem os ouvidos com cera e que atassem ele próprio ao mastro do navio, de modo que aqueles não ouvissem os cantos das sereias e este conseguisse escutar, mas sem ter o perigo de se atirar ao oceano. Uma cena que ilumina e muito a própria reificação, pois, ainda vivos, padeceriam de duas manifestações desta: "aos remadores coube a alienação direta, física, dos produtos da alta cultura; ao seu senhor estava reservada a mera contemplação da beleza, sem qualquer possibilidade de sua experiência plena" (Ibid., p. 14). Uma reificação, para ir direito ao ponto, que deitava as raízes antes do capitalismo, mas que encontrou nesse período histórico o seu "apogeu", dado que todas as promessas emancipatórias encerradas no Esclarecimento e, de certa forma, na dominação da natureza, tornaram-se o seu contrário: mitologia e barbárie ${ }^{26}$. De mãos dadas com essa crítica, há uma crítica imanente do progresso, o qual, diferentemente do que antes se pensava, carrega

\footnotetext{
${ }^{26}$ Para ficar com a famosa expressão: "o mito já é esclarecimento e o esclarecimento acaba por reverter à mitologia" (ADORNO \& HORKHEIMER, 2006, p. 15).
} 
elementos destrutivos e não a redenção pura e simples. Nas palavras dos autores, a questão seria: "nada menos do que descobrir por que a humanidade, em vez de entrar em um estado verdadeiramente humano, está se afundando em uma nova espécie de barbárie" (ADORNO \& HORKHEIMER, 2006, p. 11).

De posse disso, sigo de perto a argumentação de Arantes quanto a relação dessa Dialética do Esclarecimento com a dialética regresso-progresso de um capitalismo que comportava tanto a civilidade francesa, quanto a barbárie colonial, ambas conectadas pelas reviravoltas do capital. Segundo Arantes, pode-se dizer o seguinte quanto a Dialética do esclarecimento e sua figuração periférica:

\begin{abstract}
Dialética naquela fórmula quer dizer então, além de reviravolta e desengano prático, igualmente crítica imanente, pois o limite do Iluminismo é fixado por ele mesmo - não há outra norma além da própria emancipação. Ora, objetivamente, nossa dualidade colonial - burguesa sendo ela mesma um desenvolvimento moderno do atraso - como lembra Roberto, passando a limpo mais uma vez o momento menos vulnerável do antigo raciocínio dualista -, não estávamos para o progresso como a aberração para a norma, o desvio para o avanço uniforme, pelo contrário, como a atualidade mundial expunha seus segredos na periferia do capital, que não era resíduo mas parte integrante de uma evolução de conjunto, por assim dizer constituíamos uma figura viva daquela mesma Dialética da Ilustração. Noutros termos, este um dos aspectos do passo globalizante inerente ao esquema crítico de Roberto Schwarz. A seguir o autor mostrará de mil maneiras como a prosa machadiana, ao desmanchar a estampa moderna de nossos figurões, sem elogiar o atraso ia desqualificando o progresso, do qual aquele fazia parte. No mundo das Memórias Póstumas a totalidade das luzes contemporâneas se apresentam subordinadas a um princípio contrário ao delas, o capricho de um narrador inconstante que vai rifando uma a uma as aparências ilustradas que compõe a imagem da civilização (ARANTES, 1992, p. 97).
\end{abstract}

Toda aquela volubilidade narrativa - algo que será melhor enfrentado posteriormente exige uma série de recursos intelectuais das Luzes, uma posição totalmente esclarecida que era sistematicamente passada para trás em prol das transgressões de um Brás Cubas. Nesse sentido, existem momentos em que o iluminismo do narrador era destacado, contudo a sua conduta volúvel sempre, de uma forma ou de outra, lembra ao leitor uma conduta sempre aquém da ilustração e que destoava de uma postura esclarecida. Em suma, é como se em terras brasileiras, a Ilustração, divorciada de seu ímpeto reformador, torna-se exatamente o seu contrário, resultando em um "estoque de aparências modernas oferecidas à dissipação de um homem culto" (Ibid., p. 98). E aí está a chave comprometedora, visto que "a lepidez ideológica deste mesmo homem culto é um resultado da Ilustração: sem o processo do qual ela é o resultado a Aufklärung

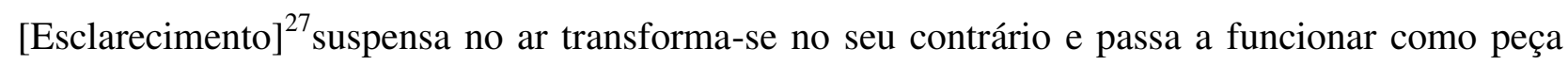
chave da apologética oligárquica" (Idem). Pretendemos melhor explorar este ponto nos parágrafos que seguem.

\footnotetext{
${ }^{27}$ Preferiu-se manter o termo em alemão em vários momentos do texto, até porque este possui uma grande amplitude de significados, os quais dificultam-lhe a tradução certeira por Iluminismo, por Ilustração ou Esclarecimento. Para mais ver a nota preliminar de tradução de Guido Antonio de Almeida em a Dialética do Esclarecimento: fragmentos filosóficos (ALMEIDA, 2006).
} 


\section{Figuras periféricas da Dialética da Ilustração, ou a dialética negativa à brasileira}

Antes de adentramos no cerne dos argumentos de nosso crítico sobre Machado de Assis, é preciso ter em vista alguns elementos que foram fundamentais para que atinasse com a volubilidade do narrador machadiano e com a atualidade crítica deste. Além da nova intuição sobre o Brasil advinda do Grupo de estudos sobre $O$ capital, em que as peculiaridade sociais, políticas e econômicas do Brasil, principalmente as formas de exploração e dominação, deveriam ser colocadas como "mediadoras, no contexto do capitalismo mundial" (SCHWARZ, 2009b, p. 232), é preciso ter em vista os pontos a seguir elencados: i) o golpe de 1964 e o progresso perverso à brasileira; ii) a publicação de "Dialética da Malandragem" de Antonio Candido e iii) a leitura de Adorno e as ideias, tanto de uma dialética negativa, quanto de que processos históricos podem não levar a uma síntese positiva ou emancipadora (SCHWARZ, 2016, informação $\operatorname{verbal}^{28}$ ). Com o intuito de aquilatar os elementos acima expostos, passaremos em revisão alguns argumentos lançados pelo próprio Schwarz e por Arantes, e, posteriormente, entraremos mais detidamente na parte da exposição de nosso crítico sobre a forma narrativa machadiana, bem como suas consequências críticas nada provincianas. Antes, porém, de aprofundarmos a argumentação é preciso deixar claro que com a exposição de partes mais aparentemente "autobiográficas" de Schwarz não pretendemos fazer um estudo detalhado de sua trajetória intelectual, mas, tão-somente, ilustrar pontos que achamos essências de seu programa crítico negativo.

Segundo o nosso crítico, com a promulgação do Ato Institucional $\mathrm{n}^{\circ}$ 5, em 1968, a repressão tornou-se insuportável, inclusive para ele, que havia se envolvido na resistência, mesmo que modestamente, contra o regime ditatorial instaurado no Brasil, levando-o a ir para a França em 1969. Já instalado, conheceu Violeta Arraes Gervaiseau, a qual recomendou-o aos responsáveis pelos assuntos brasileiros do jornal Le Monde Diplomatique, que, por sua vez, pediu um artigo sobre a situação cultural brasileira a Schwarz. O texto deveria ter quatro páginas e ter sido entregue rapidamente, porém o dito cujo nasceu apenas seis meses depois e contava com quarenta folhas, intitulado: "Cultura e política: 1964-1968" (SCHWARZ, 2008, p. 70 - 112). Neste ensaio, o crítico literário teve a oportunidade de passar a limpo, refletir e escrever o que havia visto nos anos anteriores no Brasil, estando com o país na cabeça e atualizado pôde então utilizar da liberdade literária tragicamente propiciada por sua situação de exilado (SCHWARZ, 2009b, p. 238).

\footnotetext{
${ }^{28}$ Comunicação pessoal dada por Roberto Schwarz aos alunos da disciplina Pensamento e política no Brasil: o Seminário Marx (1958-1964), ministrada pelos professores André Singer e Bernardo Ricupero. [11.outubro.2016]. São Paulo. 1 arquivo .mp3 (120 min.).
} 
Seguindo as lições de Arantes, é possível vislumbrar neste profícuo período da década de 1960, o registro e entendimento do fato de que em 1964 as marchas da Família com Deus pela Liberdade levou às ruas uma mistura propriamente belmiriana de incompatíveis, até porque a "acomodação desconforme de antigo e moderno que a crise precipitara e monumentalizava era de fato uma constante de nossa formação, como atestava, revista num relance decisivo, o conjunto de nossa história literária” (ARANTES, 1992, p. 59). De outro lado, a modernização conservadora levada a cabo no período ditatorial, ao mesmo tempo em que colocava o atraso brasileiro na atualidade internacional, também conseguia mostrar a ligação extremamente importante entre a dualidade nacional e dependência, sendo esta vista como desdobramento do descompasso estrutural expresso pela primeira. Mas do que se trata essa mistura formalizada por Schwarz e assinalada por Arantes?

Retomando o fio da meada, é no ensaio sobre o livro de Ciro dos Anjos, $O$ amanuense Belmiro, publicado nos primeiros anos de 1960, que pela primeira vez nosso autor irá atinar com aquilo que será seu raciocínio crítico posterior, cuja melhor constituição e acabamento darão notícias tanto no artigo crítico ao raciocínio político de Oliveiros Ferreira, passando pelo ensaio citado acima sobre a situação cultural brasileira e até seus livros sobre Machado de Assis. De acordo com Arantes, é de se notar que o contraponto entre cidade e campo tem uma resolução um tanto quanto incomum, pois como não houve nenhum tipo de transformação radical entre o presente urbano e o passado rural, constitui-se uma verdadeira promiscuidade entre o "moderno" e o "tradicional", mas não o conflito e desintegração esperado de ambos. Uma verdadeira duplicidade, a qual é preciso reter, visto que o narrador belmiriano realça-a por meio de uma ironia de segundo grau, a qual fixa bem seu perfil e o movimento dos personagens do romance, com um inventário de incongruências, das quais citamos as seguintes: "literato democrata e racionalista, Belmiro ri do vô patriarca, cujo extinto brilho rural no entanto o esmaga; (...) já o pai de família é antes de tudo um filósofo, mas filósofo cujo élan especulativo é ameno (ou descabelado) o bastante para recomendá-lo a quem de direito e adiantar-lhe a carreira" (ARANTES, 1992, p. 57). Desta feita, a mistura belmiriana é um retrato do Brasil, no qual desponta uma constelação dual cujos componentes se desvalorizam reciprocamente. Mesmo central e destinada a um grande futuro explicativo, esta visão ainda não constitui o nervo da demonstração (Ibid.). Assim, o que em Machado era fundamental para a sondagem desabusada da experiência brasileira, veio a ser com o tempo instrumento de uma estética acomodatícia, a partir da qual Schwarz dava pela primeira vez com seu esquema posterior.

Nas palavras do próprio crítico literário:

Mas a ideia básica de meu trabalho eu tive cedo. Foi mais ou menos o seguinte: eu lia Machado e achava a ironia dele especial. Tinha a impressão de que havia naquele tipo de humorismo, de gracinha metódica, alguma coisa brasileira. Então saí atrás disso. Combinei a tentativa de descrever a ironia de Machado com a intuição de que ela seria 
nacional - o que restava explicar. Combinei um close reading dessa ironia com a teoria do Brasil do seminário do Capital. A ideia de que a substância da ironia machadiana tinha a ver com a mistura de liberalismo e escravismo no Brasil me veio cedo, antes de 1964. Agora, daí a escrever sobre isso vai um pedaço (SCHWARZ, 2012b, p. 286) ${ }^{29}$.

Voltado aos disparates dos incompatíveis, o golpe de vista que revelaria a força crítica de Schwarz está em redescobrir como um dos primórdios dessa constelação iníqua, literária e social, a armação narrativa de Machado de Assis, "deixando-se levar pelo fio condutor da sintaxe binária do sistema cultural brasileiro, sobre cuja gênese o desfecho de 1964 lançara nova luz” (Ibid., p. 59 - 60). Contudo, o lugar da forma quando da fixação literária não seria possível sem o ensaio de Antonio Candido (2010, p. 17 - 49) sobre o romance Memórias de um sargento de milícias, de Manoel Antônio de Almeida, uma vez que algo do movimento caprichoso entre os dois polos antitéticos da ordem e da desordem está fortemente presente nos romances maduros de Machado de Assis e na volubilidade de seu narrador. Desta feita, é possível vislumbrar que os elementos anteriormente expostos foram essenciais ao nosso crítico, o qual quando perguntado se havia começado o projeto sobre Machado na França, responde:

\begin{abstract}
Não, levei daqui o assunto e algumas ideias, sobretudo a convicção de que o humorismo tão cosmopolita de Machado tinha a ver com as particularidades nada cosmopolitas do escravismo brasileiro. A caracterização do humorismo já estava na minha cabeça, faltava a conexão com o Brasil. Eu ruminava a tese do Fernando Henrique sobre Capitalismo e escravidão, e não achava a ponte. Aí reli o livro de Maria Sylvia sobre os homens pobres na sociedade escravocrata e tive um estalo: os dois trabalhos fixavam faces complementares de um mesmo processo, descreviam dois aspectos da liberdade incivil que têm as nossas classes dominantes em relação a seus dependentes. Em versão analítica, tratava-se das ambiguidades que o humorismo machadiano explora e dramatiza do ângulo social dos de cima. O esquema das 'ideias fora do lugar' e de todo o meu trabalho machadiano estava pronto (SCHWARZ, 2009b, p. 238).
\end{abstract}

Diante desse quadro explicativo, é interessante salientar novamente, ainda, a presença de Adorno na formação de nosso crítico, visto que este, apesar de ter, seguindo o depoimento de Schwarz, sido mais importante na construção e aprendizado de uma noção de forma dialética - em que esta constitui-se como conteúdo sócio-histórico sedimentado -, abriu ao nosso crítico a possibilidade de uma visão mais sóbria, aberta e até pessimista sobre a história e seus processos principalmente se levarmos em conta as teses sobre a dialética da Ilustração e suas consequências expostas sumariamente na seção sobre sua formação. Ou, parafraseando o autor, Adorno havia ensinado que a dialética pode simplesmente não acabar bem e não resolver nada, algo que, pós-64, passava a ser de grande interesse para qualquer intelectual marxista, pois armado deste ponto de

\footnotetext{
${ }^{29}$ Fiquemos com este trecho de outra obra: "O festival de desfaçatez armado por nossas elites logo em seguida ao golpe, com sua salada de modernização, truculência e provincianismo, ensinava a reconhecer aspectos até então recalcados da ironia machadiana. (...) Noutras palavras, as revelações sociais trazidas pelo golpe de 64 desempoeiravam o maior de nossos clássicos" (SCHWARZ, 2015, p. 8).
} 
vista é possível vislumbrar que processos históricos podem acabar mal ou simplesmente darem em lugar algum (SCHWARZ, 2016, informação verbal ${ }^{30}$ ).

Dito isso, é possível entender melhor o encadeamento concreto das determinações anteriormente colocadas, tornando inteligível a abertura para a constituição de uma crítica negativa, faltante em outros participantes do grupo de estudos de $O$ Capital. Crítica negativa que, em um só tempo, trazia à baila uma forma de pensar não preocupada em achar uma saída ou salvação nacional baseada, via de regra, em ideais desenvolvimentistas e voltadas para o desenvolvimento das forças produtivas, algo que contribuía em direção a uma radicalização teórica com resultados fenomenais do ponto de vista da crítica da ordem mundial do capital e suas calamidades. Este ponto será melhor desenvolvido a seguir, visto que nos debruçaremos mais detidamente em alguns escritos de Schwarz sobre Machado de Assis - principalmente o segundo livro sobre o escritor brasileiro, intitulado Um mestre na periferia do capitalismo: Machado de $\operatorname{Assis}^{31}$.

Sob a batuta de nosso crítico, poder-se-ia arguir, contrariando uma série de leituras feitas sobre Memórias póstumas de Brás Cubas, que o narrador, que invade constantemente as cenas e conturba o andamento do romance, não teria a ver com um simples traço psicológico do escritor, com uma deficiência narrativa, ou algum tipo de metalinguagem, mas sim traria em si dois sentidos importantes: “a) como regra de composição narrativa e, b) como estilização de uma conduta própria da classe dominante brasileira" (SCHWARZ, 2012d, p. 18). Nesse sentido, o crítico austro-brasileiro passa a enfatizar algo inédito dentro dos estudos machadianos, que ou era simplesmente deixado de lado, ou era tomado como fraco, a saber: a composição de sua obra.

Uma espécie de composição sui generis, a qual conta com um narrador voluntariamente inoportuno, sem credibilidade, possuidor de um humor, para não dizer aterrador, com uma grande disposição escarninha, praticante do abuso do abuso - dizendo algo, para desdizer logo depois, vestindo uma feição, para vestir outra em seguida - e essencialmente volúvel. Além da existência deste narrador volúvel, há uma postura de desrespeito contínuo em relação às normas, sejam quais forem, acentuando os aspectos mais autoritários e perversos da volubilidade; movimento cujo desdobramento também se dá no plano da forma, com uma infinidade de modalidades literárias, já que a partir de um sentimento de superioridade trocam-se constantemente os mais diversos estilos, gêneros e escolas. Fazendo pouco de todos os conteúdos e formas que aparecem nas Memórias, subordinando-os, de uma maneira que a volubilidade passa a ser princípio formal do livro.

\footnotetext{
${ }^{30}$ Comunicação pessoal dada por Roberto Schwarz aos alunos da disciplina Pensamento e política no Brasil: o Seminário Marx (1958-1964), ministrada pelos professores André Singer e Bernardo Ricupero. [11.outubro.2016]. São Paulo. 1 arquivo .mp3 (120 min.).

${ }^{31}$ Ressaltamos que o desenvolvimento de seus estudos sobre forma e processo social em Machado de Assis não se deu sem impasses e críticas - por vezes mais voltadas para o ensaio "As ideias fora do lugar" -, como as de Carlos Nelson e Maria Sylvia de Carvalho Franco, as quais não poderão ser aqui desenvolvidas, mas que foram revisitadas e bem aquilatadas por RICUPERO (2013).
} 
É importante, ainda, salientar o papel do capricho, sistematicamente encontrado nas páginas de Memórias póstumas de Brás Cubas, como um princípio geral, vislumbrado linha a linha e que a tudo se sobrepõe, o qual toma toda a experiência da humanidade e se absolutiza, contando com uma universalidade de pacotilha e uma cultura geral caricata. Um resultado à primeira vista sem muitas pretensões, mas que é um achado do escritor e do crítico, dado que essa universalização do capricho significa, segundo Schwarz (2012d, p. 33), “a incorporação dos resultados da Aufklärung, mas sem o processo correspondente, e sob uma diretriz - que resta caracterizar - oposto à ela". Este ponto já foi assinalado na seção anterior, via Paulo Arantes e será melhor retomado posteriormente, justamente com algumas considerações a respeito da dialética negativa à brasileira feitas pelo filósofo uspiano.

Quanto à forma específica do romance machadiano, há um elemento essencial em sua explicação e que ainda não foi tocado: qual é o seu referente, mimetizado na forma de prosa? À primeira vista, remeter-se-ia a dita cuja às flutuações individuais do autor, fazendo de seu capricho individual uma regra de composição, como queria Augusto Meyer (2015) e que seria possivelmente comprovado por uma miríade de borboleteios metafísicos do autor, essencialmente estranhos ao âmbito nacional, exatamente o contrário da tese de Schwarz:

\footnotetext{
Nossa tese, de cujo bem-fundado tentaremos convencer o leitor, vai na direção contrária: sem prejuízo do raio de ação ilimitado, e, neste sentido, universal, a volubilidade do narrador e a série dos abusos implicados retêm a feição específica, ou, para falar com Antonio Cândido, configuram a "redução estrutural" de um movimento que a circunstância histórica impunha — ou facultava, conforme o ponto de vista — à camada dominante brasileira. A explicação deste passo requer um momento de reflexão extraliterária, cuja pertinência, impossível de provar por $a+b$, se documenta na compreensão acrescida que acaso permita (SCHWARZ, 2012d, p. 35).
}

Tal reflexão extraliterária e histórica será feita aqui rapidamente. De acordo com Caio Prado Jr. (2011), em quem Schwarz claramente fia-se a fim de construir esse quadro explicativo, mesmo com a emancipação política brasileira que alçava o país na nova ordem do capital, houve a manutenção das mesmas relações econômicas coloniais, mantendo-se escravos, senhores, homens e mulheres livres e pobres - ou, como dizia o mesmo Prado Jr. (2011), setor inorgânico -, além da própria monocultura de exportação. Manutenção ocorrida em contexto local, mas que, porém, ainda nos inseria subalternamente no movimento do capitalismo internacional. Quanto às ideias, as justificações criadas pela colonização e o absolutismo caíam em descrédito, entrando em cena as ideias liberais oitocentistas - ao modo do Estado Nacional, Trabalho Live etc. -, tendo a Inglaterra como vanguarda industrializada e desenvolvida. Mas o que a persistência desse sistema produtivo significava e acarretava? Schwarz responde que a ligação brasileira à ordem revolucionária do capital e das liberdades civis não mudava os modos atrasados de se produzir, “como os confirmava e promovia na prática, fundando neles uma evolução com pressupostos 
modernos, o que naturalmente mostrava o progresso por um flanco inesperado" (SCHWARZ, 2012d, p. 37).

Ou seja, esse mesmo trabalho colonial, sem direito algum, passava a ser aproveitado pela classe dominante recém-constituída, o que fazia com que essa mão de obra sem cidadania ou direitos alguns não fosse mais considerada uma sobrevivência passageira e sim "parte estrutural do país livre, a mesmo título que o parlamento, a constituição, o patriotismo revolucionário etc., igualmente indispensáveis" (Ibid.). Do ângulo prático, uma necessidade contemporânea, do efetivo, uma presença tradicional e do ideológico, um arcaísmo - todos contraditórios, porém verdadeiros da perspectiva histórica dos de cima. A mesma variação de apreciações pode ser encontrada em relação ao ideário liberal, pois ao mesmo tempo que representa o progresso, já que necessário a organização do Estado e das elites, não consegue expressar coisa alguma das "relações de trabalho efetivas, as quais recusa ou desconhece por princípio, sem prejuízo de conviver com elas" (Ibid., p. 174). Tendo isso em vista é que se pode compreender seu funcionamento específico por aqui, "sem compromisso com as obrigações cognitiva e crítica do Liberalismo, o que abala a credibilidade deste último e lhe imprime, a par da feição esclarecida, um quê gratuito, incongruente e iníquo" (Ibid.).

Tal relação complementar entre instituições burguesas e coloniais esteve na origem da nacionalidade e até hoje se faz presente no Brasil, um desvio e tanto do modelo anglo-francês e que muito servia para a reflexão crítica e literária em relação ao país, mas não só. A conjunção serve para recordar o fato de que na Divisão Internacional do Trabalho, aquela miríade de excolônias assumiram o papel de exportadores de produtos tropicais e importadores de manufaturas e produtos com 'alto valor agregado', estendendo o desenvolvimento moderno do atraso ao mundo todo e não apenas ao Brasil. Reposição moderna do atraso que tem seu fundamento naquela bela formulação trotskiana, a qual identifica haver no capitalismo um desenvolvimento desigual e combinado, "expressão que designa a equanimidade sociológica particular a esse modo de produção, o qual realiza a sua finalidade econômica, o lucro, seja através da ruína de formas anteriores de opressão, seja através da reprodução e do agravamento delas” (Ibid., p. 39). Em resumo:

\footnotetext{
Contrariamente ao que as aparências de atraso fazem supor, a causa última da absurda formação social brasileira está nos avanços do capital e na ordem planetária criada por eles, de cuja atualidade as condutas disparatadas de nossa classe dominante são parte tão legítima e expressiva quanto o decoro vitoriano. Isso posto, digamos que o Brasil se abria ao comércio das nações e virtualmente à totalidade da cultura contemporânea mediante a expansão de modalidades sociais se estavam tornando a execração do mundo civilizado (Ibid.).
}

Deste modo, é importante notar que a forma da prosa machadiana madura internaliza implicações estruturais do quadro histórico exposto acima e na seção anterior, pois é parte da 
volubilidade esse consumo breve de ideias, convicções, modos literários, posturas, logo desqualificadas e abandonas em prol de outras. Movimento que lança mão de toda sorte de soluções e aparências esclarecidas, destratando, ao fim e ao cabo, posturas e anseios iluministas, subordinadas a um princípio alheio ao delas, tirando-lhes sua credibilidade. Não é outro o movimento da classe dominante brasileira tomada em bloco, já que deveria absorver os aspectos culturais relevantes à época e as conquistas civilizacionais coetâneas, "para praticamente aclimatá-las no país, ou seja, associá-la ao instituto da escravidão, cujo núcleo de dominação pessoal discricionária contudo zombava da pretensão civilizada e já não era sustentável de público" (Ibid., p. 41). Em suma, uma legitimação apoiada em razões de ser antagônicas, questão que traz um bom quilate de inquietação; de todo modo, são esses os elementos em comum entre a forma e malformação nacional, digamos.

Continuando o argumento, Schwarz identifica no movimento de volubilidade avaliações que se contradizem, diagramas sequenciais que se opõe, os quais tomam a Razão e sua posição histórica ou como ultrapassada ou como inalcançável. Ambivalência muito bem fundada nas elites brasileiras, que se queriam parte de um Ocidente já burguês, culto e progressista - correspondente à norma -, sem prejuízo de se beneficiarem de um dos últimos sistemas escravocratas do mundo, em outras palavras, da mais abjeta barbárie - correspondendo à infração. Ou seja, os setores da sociedade brasileira que se queriam europeus participavam da civilização burguesa, mas de modo peculiar, dado que a invocavam e descumpriam de modo indefinido e alternado. Situação que condicionava um comportamento que, ao mesmo tempo, valoriza e despreza a norma, difundindo uma oscilação de critério muito bem expressa por Machado de Assis e imputando à consciência burguesa uma série de acrobacias, as quais poderiam incomodar e muito a consciência crítica. Trocando em miúdos:

(...) além da infração, a infração é norma, e a norma, além de norma, é infração, exatamente como na prosa machadiana. Em suma, a defesa progressista do tráfico negreiro suscitava problemas ideológicos difíceis de resolver, e encarnava a parte de afetação e afronta que acompanha a vida das ideias nas sociedades escravistas modernas. A ambivalência tinha fundamento real, e Machado de Assis, conforme se verá, soube imaginar-lhes as virtualidades próximas e remotas (Ibid., p. 43).

Em Memórias póstumas a expansão do capricho é completa, submetendo todos os assuntos possíveis e imagináveis, o que requer um grande grau de invenção literária. Mas há um ponto importante levantando pelo crítico austro-brasileiro: o narrador faz sempre figura inferior, pois algo em suas convicções não convence e configuram, em série, uma derrota completa. Mas como poderia se dar esse efeito de diminuição e superioridade simultâneos? Bem, a volubilidade precisa ser entendida como um dispositivo relacional, que se concebe tendo em vista o padrão burguês de constância e objetividade, reconhecendo-lhe certa primazia, ao mesmo tempo que afirma a sua primazia via desrespeito, forjando um movimento cuja lei é o constante reconhecimento e 
desconhecimento. Em resumo, apesar de estar em negativo, o espírito burguês constitui a volubilidade do narrador machadiano, trazendo dentro de si o ponto de vista que o faz aparecer como deficiência, podendo ser registrada tanto em termos metafísicos - a precariedade da humanidade como um todo - e em registro histórico - sinal de atraso do Brasil, devendo ser compreendidos em sua coexistência, com o intuito de interpretá-la melhor.

Sendo assim, a volubilidade se constitui como "uma feição geral a que nada escapa, sem prejuízo de ser igualmente uma tolice bem marcada, de efeito pitoresco, localista e atrasado" (Ibid., p. 45). Funcionando como base de verdade da conduta humana - até hoje, inclusive -, essa incerteza que baseia o romance de modo algum pode ser tomado como uma fraqueza e sim um "resultado artístico de primeira força, que dá a objetividade da forma a uma ambivalência ideológica inerente ao Brasil de seu tempo" (Ibid., p. 46). O critério ilustrado, burguês e europeu, que vê o capricho como uma volubilidade, não é menos nosso ou real, do que "o critério emanado de nossas relações sócias não burguesas, em que o elemento de arbítrio pessoal sobressai, ponto de vista que por sua vez detecta e assinala a presença do capricho em toda parte” (Ibid.), ainda mais em relação a pretendida objetividade do primeiro, que o condena. Mas qual partido tomar aí? As duas apreciações são reais, porque calcadas no interesse prático da mesma classe social, ligada tanto à regra burguesa, quanto aos aspectos mais abjetos do clientelismo e da escravidão, destarte, mais verdadeira que o antagonismo era sua acomodação, "incongruente e vantajosa, uma das marcas da inscrição ‘teratológica' do país na cena contemporânea” (Ibid.). Seguindo Schwarz:

\begin{abstract}
A forma, acompanhando neste ponto o cotidiano das classes dominantes, não trata de dramatizar e levar ao desfecho - que seria irreal - a oposição entre aqueles pontos de vista. Mas vai além, na medida em que os faz coexistir e revezar em espaço ultra-exíguo, com ânimo sistemático, sublinhando e apurando os efeitos desencontrados do seu convívio. Resulta uma alternância com muito alcance brasileiro e satírico, onde a inconsistência de critério, ou melhor, a dualidade das medidas figura como realidade permanente e inexorável, prova simultânea de inferioridade e superioridade que contextualiza na íntegra as matérias do romance. Para complicar, note-se ainda que a estilização machadiana da preeminência local do capricho se faz segundo o modelo literário da whimsicality inglesa (Ibid.).
\end{abstract}

Em suma, é da formação de uma forma dialética adequada à realidade nacional, diversa mas não alheia, de que se trata. Forma que, segundo Waizbort (2007), estaria ligada a uma discussão mais densa sobre o(s) realismo(s), visto que ao indexar o limite do realismo de Machado à situação histórica na qual se encontrava - um limite histórico e objetivo, tanto para a obra, como para o escritor -, Schwarz, em discussão direta com Lukács e seus textos sobre realismo, indica como em situações históricas outros problemas assemelhados aos do romance europeu e sua feitura, encontram uma forma literária própria. Destarte, os livros sobre Machado seriam além de livros sobre o Brasil, como fora exposto anteriormente, contribuições locais "à compreensão dos problemas da forma literária e de sua relação com a realidade" e, de quebra, 
intromissões poderosas "no debate sobre o(s) realismo(s), além de uma contribuição a uma estética marxista"(WAIZBORT, 2007, p. 53).

Com o intuito de finalizar a seção e retomar alguns pontos explorados, passo agora a seguir algumas observações importantes de Arantes. O filósofo uspiano argumenta que a sondagem machadiana da experiência brasileira, baseada em Schwarz, induz a visão de algumas figuras diferentes da dialética, as quais exporei agora. A primeira figura concerne à relação dialética entre forma e conteúdo, cuja acepção é de inspiração materialista, já explorada em boa parte da argumentação anterior e possuidora de dois momentos: i) a junção do romance e da sociedade, via "forma bifronte na qual está cifrada a percepção básica de uma dualidade, a um tempo estrutura e fundamento prático - histórico" (ARANTES, 1992, p. 91); ii) este momento diz respeito a passagem de um primeiro Machado, conformista, ao romancista maduro da segunda fase, uma passagem que resolve "um problema objetivo de acumulação artística, quando então se completa a formação do nosso sistema literário, tal como concebera Antonio Candido” (Ibid.).

Passo à segunda figuração da dialética, agora negativa, pois, ao que nos consta, a reversão constante entre infração e norma, movimento definidor da caprichosa gangorra em que o narrador machadiano balança, consegue estilizar a convivência desmedida de País Burguês e Antigo Regime colonial; verifica-se também que essa mesma lógica dual faz pulsar o andamento tanto da prosa artística, quanto o ritmo da sociedade em questão. Nesse sentido, amparados em uma velha fórmula de Candido (2010, p. 17 - 49), retirada de seu famoso ensaio "Dialética da malandragrem”, no qual também atinou com o igual fundamento prático na dualidade de nossa formação nacional específica, poder-se-ia chamar essa pulsação de dialética e mais ainda: uma dialética sem síntese, ou negativa, em que esses "Dois Brasis" eram articulados. Chamando-a negativa, estar-se-á "dando um nome que consta do repertório clássico mas traduz o timbre específico do segundo Machado, especializado, como se sabe, no capítulo das negativas. Ocorre que esta denominação - complicando um pouco a tarefa do comentário - contraria uma outra acepção clássica do termo, que associa dialética e prosa realista do grande romance oitocentista" (Ibid., p. 93).

Lembrando Schwarz, Machado havia escrito romances realistas utilizando-se de recursos nada realistas - como é o caso da volubilidade do narrador de Lawrence Sterne ${ }^{32}$ - o que teria como consequência a convergência de dialética, via brasileira para o mundo do capital, como fica claro nas questões do realismo. Segundo o crítico austro-brasileiro, o capricho derrotaria a subjetividade burguesa pautada na consistência, descartando também o próprio recorte

\footnotetext{
${ }^{32}$ Aqui é interessante seguir a sugestão de Arantes (1994, p.228), para quem a partir do ensaio "A tribulação de um pai de família" (SCHWARZ, 2008, p. 22-29), seria possível notar na obra de Schwarz a convicção de que procedimentos anti-realistas além de engendrarem resultados realistas, podem ser os únicos, no capitalismo tardio, a produzirem uma crítica da aparência nas artes.
} 
individualista presente no Realismo, armando-se, desse modo, "um 'enredo vadio', sem tensão onde a trama não é retesada por nenhum conflito, nenhuma corrente central, assim sendo, o tempo é improdutivo, não pressiona na direção de qualquer progresso, não enquadra enfretamento algum de posições" (Ibid.), decorrendo daí inexistência de personagens definidores, inviabilizados pela patronagem.

O que é um achado de Schwarz, argumentando que, entre a sua primeira e segunda fases, Machado via que a "marcha recalcitrante do Brasil para o mundo moderno rifava a dialética de indivíduo e sociedade, matriz da estética realista" (Ibid., p. 94). Em síntese, como o processo de aburguesamento do Brasil não se desenrolou à europeia, a dialética clássica era deixada de lado e em seu lugar, surgia uma outra, negativa, que rege um constante girar em falso de animação e fastio, por exemplo, dialética negativa que se apresenta como uma hélice "que empurra a narrativa machadiana em direção ao nada" (Ibid.). À diferença de um enredo realista europeu assentado no desmascaramento da alienação por meio do registro da ilusão perdida, o enredo de Machado narra uma existência sem sentido algum, porém repleta de satisfações. Quer dizer, perante a Europa, a volubilidade é nula, mas se confrontada com o sistema de relações locais é tudo, um niilismo que exprime a pressão ao mesmo tempo inócua e real do molde burguês de civilização, de modo que se as iniquidades do Brasil dão em nada, nem por isso tem um fim em vista, como diria Schwarz. Nesse diapasão Arantes formula uma comparação sugestiva entre a dialética negativa à europeia e daqui:

\begin{abstract}
Na Europa, a dialética negativa anunciava o contrário, o nascimento moderno do sujeito sem tutela, o momento quase libertário de indefinição entre o Antigo Regime agonizante e a nova ordem burguesa ainda não estabelecida. Foi assim com o discurso ilustrado francês - basta pensar em obras-primas do sentimento nascente da dialética como Le Neveu de Rameau e Jacques le Fataliste. Mais adiante, já para o fim deste primeiro período, ela ainda se apresentaria na existência irônica do intelectual alemão de vanguarda, encarnada nos românticos de lena: a tendência do Witz ao niilismo era a um tempo expressão de uma subjetividade reforçada em sua soberania pela desidentificação irônica com conteúdos positivos e prenúncio de um esvaziamento estetizante que se avizinhava. O discernimento infalível de Machado levou-o a reanimar esse esqueleto da dialética em estado bruto na sua dimensão degradada posterior ao contravapor de 1848 , depois do fiasco da fraseologia burguesa, divisando o valor mimético e o alcance crítico da operação. É o que sugere Roberto em terminologia e referências diversas, noutro de seus achados. Veja-se a solução que encontrou para a apropriação machadiana do humorismo inglês do setecentos, ao mostrar como o romancista, usando técnicas narrativas de 1750 no espirito esteticista fin de siècle, obtinha efeitos modernos com recursos arcaizantes, por assim dizer imitando mais urna vez a dinâmica da combinatória brasileira. Mais exatamente, uma forma que estivera ligada ao impulso de emancipação das Luzes servia, quando se trazia para o primeiro plano sua índole autocomplacente, para retratar o esclarecimento barateado de nossas elites (Ibid., p. 95 - 96).
\end{abstract}

Algo que faz sistema com o que já fora dito anteriormente sobre a desclassificação da totalidade das Luzes pelo capricho no narrador machadiano - lembrando que a mola do mecanismo satírico armado por Machado é baseado no aproveitamento conservador da última palavra no quesito progresso -, passando a funcionar como peça central na apologética oligárquica, que por sua vez anda de mãos dadas com o tópico sobre a Dialética do 
Esclarecimento e as suas figuras na periferia do capitalismo, visto que a conversão original do universalismo da Ilustração em ideologia é um dos tópicos essenciais desta e um procedimento lapidar na prosa e na forma machadiana. Repertoriar as consequências excêntricas que ciência e progresso iam assumindo no Brasil vem a ser uma das maneiras de indicar que dialética e crítica imanente da ideologia andam juntas, ao menos desde os tempos em que o ressurgimento moderno da dialética "apresentou-se antes de tudo como uma teoria da consciência aparente, porém concebida de tal modo que a própria consciência traria em si mesma a medida da sua verdade e da sua falsidade.” (Ibid., p. 98) Em resumo: dialética entendida como o confronto interno do objeto com o seu conceito mesmo, contando com um momento de negação que é a denúncia de promessas não cumpridas; uma crítica da aparência existente desde o alvorecer da consciência moderna e da autonomia e que passou para o campo da esquerda já em 1848, quando a perspectiva crítica fora abandonada pela burguesia e tudo isso tendo em vista uma constelação presente na periferia do capitalismo.

$\mathrm{O}$ atraso reproduzido pelo processo de modernização dá, à experiência brasileira, um ponto de vista especifico, convergente com os efeitos nos países centrais consequentes do colapso da tradição burguesa, o que em outras palavras pode ser colocado do seguinte modo: a ação de dissolução operada pelo capricho teve por consequência a desprovincianização do Brasil, dado que repertoriando a dimensão não burguesa da existência burguesa brasileira, cujo "elenco de violações cometidas pela fala volúvel do narrador machadiano aproximava a dita experiência coletiva da evolução ideológica do fin de siècle europeu, todo ele impregnado de impulsos antiliberais, do esteticismo às vanguardas que madrugavam" (Ibid., p. 100) ${ }^{33}$. Tirando a aura de inocência tanto do atraso, como do progresso, visto que a persistência do Antigo Regime à brasileira mostrava o intenso intercâmbio entre os dois termos e a correspondência entre centro e periferia quanto a derrocada e a troca de sinal da Aufklärung. Troca de sinal que deu-se, seguindo tanto o argumento de Marx (2011), quanto o de Lukács (2011, p. 211 - 253), após a Contra Revolução de 1848, na qual a burguesia, acossada pelos ventos revolucionários e pela força dos trabalhadores franceses, passa para o lado da Reação, colocando-se em um verdadeiro Estado de Sítio moral, a partir do qual as conquistas do Esclarecimento são destituídas de seu ímpeto civilizatório e passam a ser fundamentais para manutenção da posição perversa da classe burguesa na guerra social contra os de baixo (ARANTES, 1996, p. 32 - 52). Chão material e histórico sob o qual poder-se-ia entender o desenvolvimento e o descortinar de ideias que apontavam para um horizonte de revolução, crítica radical e experimentação estética anti-burguesa sem precedentes -

\footnotetext{
33 Fiquemos com esta passagem sobre a relação entre atraso social relativo e autocrítica da cultura burguesa, constantes nos escritos de Machado de Assis: "É natural que a autocrítica da ordem burguesa se faça, ao menos em parte, em nome das energias que ela pulverizou. Acontece que, em países da periferia capitalista, estas energias ainda se encontram soltas na rua" (SCHWARZ, 2012a, p. 196).
} 
além das ligações entre estes termos, é claro (ANDERSON, 1986) (BÜRGER, 2008). Em suma, algo de alcance mundial, feito por Machado, formalizado por Schwarz e comparável à realização da Teoria da Dependência.

Desvelando duas convergências importantes, uma da literatura central e periférica e outra de literaturas periféricas entre si, Schwarz nota uma afinidade, ou ar de família, entre a literatura pós-48, em que o "estado de sítio" - no qual a burguesia já não mais poderia vocalizar uma pretensa universalidade ${ }^{34}$ - havia sido declarado, com a guerra de classes apresentando-se como nunca antes na história, e as literaturas na franja do sistema, as quais mediam o formalismo da metrópole pelo metro das letras periféricas. Destarte a narração posta em movimento com esse novo estágio da luta de classes europeia, passa a exigir uma série de procedimentos formais nunca antes usados pelo realismo - à maneira de impessoalidade, rodízio de pontos de vista, deslocamentos para indicar a precedência da formação social em relação à individual -, as quais definem o "território exato em que reencontramos a volubilidade do protagonista machadiano, também posta à distância exclusivamente pela composição situacional” (Ibid., p. 102). Revelando uma confluência entre a reversão europeia pós-48 e o impasse moral dos de cima no Brasil.

A outra convergência se deu entre literaturas retardatárias, como a russa e a brasileira, as quais sofriam consequências muito parecidas de um sistema de ambiguidades do uso deslocado do ideário burguês (Ibid., p. 104). Em síntese, é um mesmo sistema de ambivalências que preside a vida das ideias e as perspectivas práticas na franja do mundo capitalista, uma chave real de cotejo, cuja matriz prática não é outra, senão "a razão histórico-estrutural de um vasto sistema de comparações capaz então de dar a volta ao mundo que o capital entronizou, através de uma história geral da experiência literária" (Ibid., p. 105) ${ }^{35}$. Resultados nada provincianos, em suma.

\section{À guisa de conclusão, considerações finais}

Tendo em vista o que até aqui foi exposto, é possível vislumbrar em alguns escritos de Schwarz a constituição e a consecução de um programa de crítica negativa, da qual podemos depreender uma busca por uma crítica radical à ordem capitalista mundial e ao reino da mercadoria, juntamente com suas iniquidades. Dito isto, é preciso enfatizar que o nosso crítico ao lançar mão da nova intuição sobre o Brasil, forjada em meio ao chamado Seminário Marx, grosso modo, deslocava-a em um sentido negativo, mostrando que o nosso cortejo de barbáries e iniquidades locais fazia parte da reprodução da ordem capitalista internacional. Levando-o a

\footnotetext{
34 A questão é originalmente desenvolvida por Lukács, para mais ver: "O romance histórico e a crise do realismo burguês" (LUKÁCS, 2011, p. 211 - 307).

${ }^{35}$ Ainda nesse diapasão, é interessante notar, seguindo Ricupero (2013, p.542), que os estudos de Schwarz foram essenciais, por exemplo, para a retomada da perspectiva de uma literatura mundial por Franco Morretti (2000, p. 58).
} 
formulações críticas, as quais colocavam-no juntamente com uma das expressões mais sofisticadas do ponto de vista marxiano, a saber, os frankfurtianos - ao modo de Adorno e Horkheimer -, entroncando nas teorizações destes, como quando demonstrava as figurações de certa dialética da Aufklärung. Algo diferente da maioria de seus colegas, engajados na superação de nosso atraso relativo, bem como a nossa brutal inorganicidade social e envolvendo-se sistematicamente em achar uma saída positiva e programática para o Brasil, visando um país socialmente coeso e que participasse efetivamente do progresso do capitalismo em meio ao concerto das nações.

Sendo assim, lançando mão de um ponto de vista da periferia capitalista e da experiência intelectual específica engendrada nela, Schwarz logrou forjar um programa crítico, o qual, a um só tempo, tanto produzia uma crítica ao falso senso de universalidade das categorias advindas dos países centrais, quanto constituía uma crítica radical aos pressupostos do capitalismo internacional e as reviravoltas ensejadas por este quanto às figurações do Esclarecimento e de sua dialética. 


\section{Referências}

ADORNO, Theodor W. As estrelas descem à Terra: a coluna de astrologia do Los Angeles Times: um estudo sobre superstição secundária. São Paulo: Editora UNESP, 2008.

. Filosofia da nova música. $3^{\text {a }}$ Ed. São Paulo: Pespectiva, 2011.

. Notas de literatura I. 2 ${ }^{\mathrm{a}}$ Ed. São Paulo: Duas Cidades; Editora 34, 2012.

. Teoria estética. Lisboa: Edições 70, 1970.

. Três estudos sobre Hegel. São Paulo: Editora Unesp, 2013.

ADORNO, Theodor W. e HORKHEIMER, Max. Dialética do esclarecimento: fragmentos filosóficos. Rio de Janeiro: Jorge Zahar, 2006.

ALMEIDA, Guido Antonio de. "Nota preliminar do tradutor". Em: ADORNO, T. W. e HORKHEIMER, M. Dialética do esclarecimento: fragmentos filosóficos. Rio de Janeiro: Jorge Zahar, 2006.

ALMEIDA, Jorge de. "Pressupostos, salvo engano, dos pressupostos, salvo engano". Em: CEVASCO, M.E. e OHATA, M. Um crítico na periferia do capitalismo: reflexões sobre a obra de Roberto Schwarz. São Paulo: Companhia das Letras, 2007.

ANDERSON, Perry. “Modernidade e Revolução”. Novos Estudos, v. 1, n 14, p. 2-16, 1986.

ARANTES, Otília e ARANTES, Paulo. Sentido da Formação: Três estudos sobre Antonio Candido, Gilda de Mello e Souza e Lúcio Costa. Rio de Janeiro: Paz e Terra, 1997.

ARANTES, Paulo. “Ajuste intelectual”. Em: HADDAD, F. Desorganizando o consenso: nove entrevistas com intelectuais à esquerda. Petrópolis: Vozes, 1998.

O fio da meada: uma conversa e quatro entrevistas sobre filosofia e vida nacional. Rio de Janeiro: Paz e Terra, 1996.

. Sentimento da Dialética. Rio de Janeiro: Paz e Terra, 1992.

. Um departamento francês de ultramar: estudos sobre a formação da cultura filosófica uspiana (uma experiência dos anos 60). São Paulo: Paz e Terra, 1994.

BENJAMIN, Walter. Magia e técnica, arte e política: ensaios sobre literatura e história da cultura. Obras escolhidas, vol. 1. $7^{\text {a }}$ Ed. São Paulo: Brasiliense, 2011.

BÜRGER, Peter. Teoria da vanguarda. São Paulo: Cosac Naify, 2008.

CAMARGO, Sílvio. "Os primeiros anos da 'Escola de Frankfurt' no Brasil”. Lua Nova, v. 1, no 91, p. $105-133,2014$.

CANDIDO, Antonio. Formação da literatura brasileira: momentos decisivos (1750 - 1880). $14^{\mathrm{a}}$ Ed. Rio de Janeiro: Ouro sobre azul, 2013. O discurso e a cidade. $4^{\mathrm{a}}$ Ed. Rio de Janeiro: Ouro sobre azul, 2010. 
. "Sobre Roberto Schwarz". Em: CEVASCO, M.E. e OHATA, M. Um crítico na periferia do capitalismo: reflexões sobre a obra de Roberto Schwarz. São Paulo: Companhia das Letras, 2007.

CARDOSO, Fernando Henrique. Capitalismo e Escravidão no Brasil Meridional: o negro nas sociedades escravocratas do Rio Grande do Sul. 4ª Ed. São Paulo: Paz e Terra, 1997.

CEVASCO, Maria Elisa. "O avesso do atraso: notas sobre Roberto Schwarz". Terceira Margem, v.1, no 16, p. $9-27,2007$.

; OHATA, Milton (org.). Um crítico na periferia do capitalismo: reflexões sobre a obra de Roberto Schwarz. São Paulo: Companhia das Letras, 2007.

DUARTE, Rodrigo. "Apresentação à edição brasileira". Em: ADORNO, T. W. As estrelas descem à Terra: a coluna de astrologia do Los Angeles Times: um estudo sobre superstição secundária. São Paulo: Editora UNESP, 2008.

FRANCO, Maria Sylvia de Carvalho. Homens livres na ordem escravocrata. $4^{a}$ Ed. São Paulo: Editora UNESP, 1997.

FISCHER, Luís Augusto. "Em busca do narrador: traços do pensamento do jovem Schwarz". Em: CEVASCO, M.E. e OHATA, M. Um crítico na periferia do capitalismo: reflexões sobre a obra de Roberto Schwarz. São Paulo: Companhia das Letras, 2007.

GONÇALVES, Rodrigo Santaella; BRITO, Leonardo Octavio Belinelli de. “'Nacionalização' do marxismo: os casos do Seminário d'O Capital e do grupo Comuna”. Outubro, v. 28, n. 1, p.53-80, 2017.

HOMERO. Odisseia. São Paulo: Editora 34, 2013.

HEGEL, Georg Wilhelm Friedrich. Ciência da lógica: (excertos). São Paulo: Barcarolla, 2011.

KONDER, Leandro. Orelha de livro. Em: SCHWARZ, R. A Sereia e o Desconfiado: ensaios críticos. Rio de Janeiro: Civilização Brasileira, 1965.

LAHUERTA, Milton. "Marxismo e vida acadêmica: os pressupostos intelectuais da crítica uspiana ao nacional-desenvolvimentismo". En: BOTELHO, A.; BASTOS, É. R.; BOAS, G. V. O moderno em questão - a década de 1950 no Brasil. Rio de Janeiro: Topbooks, 2008.

LÖWY, Michael. Romantismo e Messianismo: ensaios sobre Lukács e Walter Benjamin. São Paulo: Perspectiva, 2008.

LUKÁCS, György. História e Consciência de Classe. $2^{\mathrm{a}}$ Ed. São Paulo: Editora WMF Martins Fontes, 2012.

"O romance como epopeia burguesa". Em: LUKÁCS, G. Arte e sociedade: escritos estéticos (1932-1967). 2ªd. Rio de Janeiro: Editora UFRJ, 2011.

. O Romance histórico. São Paulo: Boitempo Editorial, 2011.

. A alma e as formas: ensaios. Belo Horizonte: Autêntica Editora, 2015.

MARX, Karl. O capital: crítica da economia política. Vol.1, Tomo 2. São Paulo: Nova Cultural, 1985. 
O 18 de Brumário de Luís Bonaparte. São Paulo: Boitempo Editorial, 2011.

MEYER, Augusto. "O homem do subterrâneo". Em: LEITE, A.; CECILIO, A. L.; JAHN, H. (Orgs.). Machado de Assis: obra completa em quatro volumes, vol. 1. $3^{\text {a }}$ Ed. Rio de Janeiro: Nova Aguilar, 2015.

MACEDO, José Marco Mariani de. "Posfácio do tradutor". Em: LUKÁCS, G. A Teoria do Romance. $2^{\text {a }}$ Ed. São Paulo: Editora 34, 2009.

MORETTI, Franco. “Conjuctotes on world literature”. New Left Review, v1, nº1, p. 54-68, 2000.

MUSSE, Ricardo. Cinco verbetes sobre Theodor W. Adorno, 2015 http://blogdaboitempo.com.br/2015/11/19/5-verbetes-sobre-theodor-w-adorno/. Acessado em 09/01/2016.

PRADO Jr., Caio. Formação do Brasil contemporâneo: colônia. São Paulo: Companhia das Letras, 2012.

PRESSLER, Gunter Karl. Benjamin Brasil: a recepção de Walter Benjamin, de 1960 a 2005. Um estudo sobre a formação da intelectualidade brasileira. São Paulo: Annablume, 2006.

RICUPERO, Bernardo. Caio Prado Jr. e a nacionalização do marxismo no Brasil. São Paulo: Editora 34, 2000.

2008

“Da formação à forma. Ainda as 'ideias fora do lugar'”. Lua Nova, v.1, nº 73, p. 59 - 69,

. "O lugar das ideias: Roberto Schwarz e seus críticos". In: Sociologia e Antropologia, v.3, $\mathrm{n}^{\mathrm{o}} 6, \mathrm{p} .523-555,2013$.

RODRIGUES, Lidiane Soares. A produção social do marxismo universitário em São Paulo: mestres, discípulos e "um seminário" (1958-1978). Tese (Doutorado em História Social). São Paulo: Faculdade de Filosofia Letras e Ciências Humanas, USP, 2011.

SADER, Emir. "Nós que amávamos tanto o capital: fragmentos para a história de uma geração". Sociologias, v. 2, no. 14, p.150-177, 2005.

SCHWARZ, Roberto. A Sereia e o Desconfiado: ensaios críticos. Rio de Janeiro: Civilização Brasileira, 1965.

Ao vencedor as batatas: forma literária e processo social nos inícios do romance

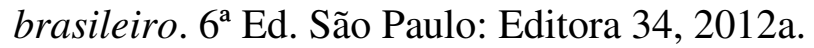

Comunicação pessoal dada aos alunos da disciplina Pensamento e política no Brasil: o Seminário Marx (1958-1964), ministrada pelos professores André Singer e Bernardo Ricupero. [11.outubro.2016]. São Paulo. 1 arquivo. mp3 (120 min.), 2016.

. "Dialética da formação". Em: PUCCI, B. et alli. Experiência formativa e emancipação. São Paulo: Nankin, 2009a.

"Entrevista". Em: MOURA, F. e MONTEIRO, P. (org.). Retrato de grupo - 40 anos do CEBRAP. São Paulo: Cosac Naify, 2009b. 
. "Entrevista com Roberto Schwarz, por Eva Corredor". Literatura e Sociedade, São Paulo, v.1, no. 6, p. $14-39,2001-2002$.

$2012 \mathrm{~b}$.

Martinha versus Lucrécia: ensaios e entrevistas. São Paulo: Companhia das Letras,

. O pai de família e outros estudos. São Paulo: Companhia das Letras, 2008.

. "Prefácio a 2 $2^{\mathrm{a}}$ edição". Em: SCHWARZ, R. A lata de lixo da história. São Paulo: Companhia das Letras, 2015.

Que horas são?. 2a Ed. São Paulo: Companhia das Letras, 2012c.

. Sequências brasileiras: ensaios. $2^{\mathrm{a}}$ Ed. São Paulo: Companhia das Letras, 2014.

. "Sobre a leitura de Marx no Brasil". Em: SCHWARZ, R. et alii. Nós que amávamos tanto

O Capital: leituras de Marx no Brasil. São Paulo: Boitempo, 2017. $2012 \mathrm{~d}$.

Um mestre na periferia do capitalismo: Machado de Assis. 2a Ed. São Paulo: Editora 34,

TAPIA, Luis. La producción del conocimiento local: historia y política en la obra de René Zavaleta. La Paz: Cides - UMSA; Muela del Diablo Editores, 2002.

WAIZBORT, Leopoldo. A passagem do três ao um: crítica literária, sociologia e filologia. São Paulo: Cosac Naify, 2007.

Aufklärung musical: consideração sobre a sociologia da arte de Th. W. Adorno na Philosophie der neuen Musik. Dissertação (Mestrado em Sociologia). São Paulo: Faculdade de Filosofia Letras e Ciências Humanas, USP, 1991.

XAVIER, Ismail. "O mundo tem as caras que pode ter." Em: CEVASCO, M.E. e OHATA, M. Um crítico na periferia do capitalismo: reflexões sobre a obra de Roberto Schwarz. São Paulo, Companhia das Letras, 2007.

Recebido em 16-03-2017;

Revisado em 03-07-2017;

Publicação em 04-05-2018. 